\title{
NEW BUILDINGS AT THE FIRE RESEARCH STATION
}

\author{
By D. I. LAWSON \\ Joint Fire Research Organization of the Department of Scientific and Industrial Research \\ and Fire Offices' Committee
}

\begin{abstract}
$\mathrm{T}$ HE new buildings of the Fire Research Station of the Joint Fire Research Organization of the Department of Scientific and Industrial Research and the Fire Offices' Committee, which have a floor area of 30,000 sq. ft., were opened on November 4 by the Right Hon. Viscount Hailsham, Lord President of the Council and Minister for Science. This new accommodation, built at a cost of about $£ 300,000$, doubles the previous floor area and makes the Fire Research Station the largest and best-equipped organization of its kind in the world.

The scheme comprises a three-storey block (Fig. 1), $200 \mathrm{ft}$. long, $36 \mathrm{ft}$. wide and $33 \mathrm{ft}$. high, of laboratories and offices and two separate blocks of three $30-\mathrm{ft}$. high laboratories, each having a floor area of about 2,500 sq. ft., for hydraulics, thermal radiation and chemical engineering research.

A 7,500-gallon concrete storage tank is built in the floor of the hydraulics laboratory to conserve water returned from experiments. Two pumps are provided in the laboratory, one having a capacity of 1,000 gal./min. at a pressure of $121 \mathrm{lb}$./in. ${ }^{2}$ and the other a capacity of $250 \mathrm{gal} . / \mathrm{min}$. at a pressure of $156 \mathrm{lb}$./in. ${ }^{2}$. These are used for testing equipment submitted by manufacturers, including alarm valves and sprinkler systems.

The radiation laboratory will be used for problems relating to ignition and spread of fire, and for this purpose a $4 \mathrm{ft}$. square gas-fired radiant panel has been installed at one end of the laboratory.

Explosion hazards of combustible dusts and the self-heating of unstable chemicals will be studied in the new chemical engineering laboratory.

The opening of the new buildings came nearly fourteen years after the formation of the Joint Fire Research Organization by the Department of Scientific
\end{abstract}

and Industrial Research and the Fire Offices' Committee. One of the principal older buildings houses furnaces for examining the performance of structural elements under fire conditions, the largest furmace having a maximum gas consumption of $25,000 \mathrm{cu}$. $\mathrm{ft}$. per hour ; indeed, the maximum total gas consumption of the Fire Research Station is sufficient for a small town.

During 1958, a large laboratory, the models laboratory, $150 \mathrm{ft}$. long, $50 \mathrm{ft}$. wide and $40 \mathrm{ft}$. high, was added to the existing buildings for the purpose of studying the modelling of fires. This has a roof which will open over $24 \mathrm{ft}$. to release smoke and hot gases. A 12-ft. diameter fan, driven by a 200-h.p. motor, can be used to draw air transversely across the laboratory at speeds up to 30 m.p.h. over a working section $15 \mathrm{ft}$. long, $15 \mathrm{ft}$. wide and $10 \mathrm{ft}$. high.

The present staff totals 136, and the scientific work of the Station is organized into five sections.

\section{Operational Research and Intelligence}

Each year this Section receives from the Fire Service Department of the Home Office details of about 120,000 fires which have been attended by local authority fire brigades. After coding and analysing them, the Section produces annual statistical tables and notes trends in the incidence of fire, casualties and damage. Detailed studies are made of specific hazards-for example, fires caused by oilburning appliances or by electricity. Investigations are also made into the effectiveness of equipment, such as sprinklers and fire-detectors. The work of this Section provides an essential background for planning the research programme as a whole and for the administration of fire protection.

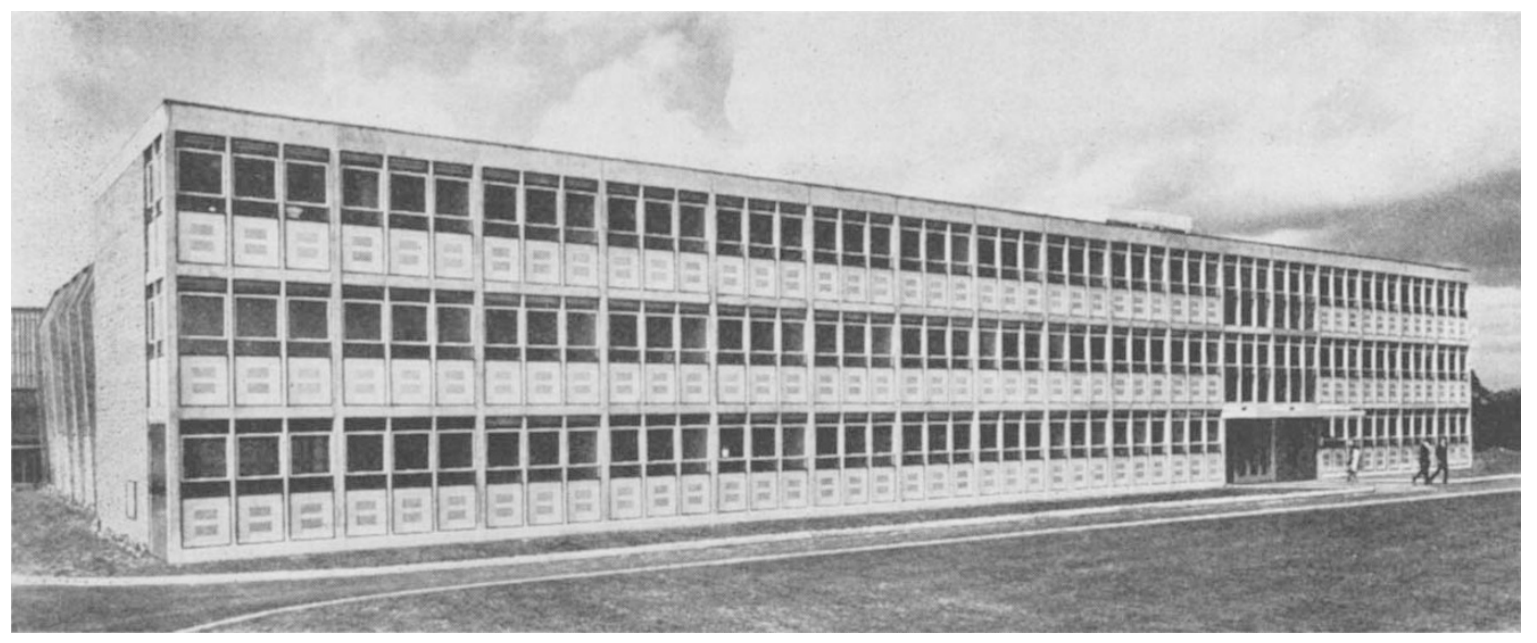

Fig. 1. The Main Building of the Fire Research Station, Boreham Wood, Herts 


\section{Ignition and Growth of Fire}

In this Section physical aspects of combustion and heat transfer are studied. Techniques involving the use of models are being developed to determine the factors-particularly wind, ventilation, fuel, and shape and size of compartment-which control the growth of fire and its spread within and between buildings. The aim of this work is to provide a scientific basis for the fire grading and adequate separation of buildings. Ten laboratories in other countries are also co-operating on an agreed programme of experiments with models. The results of this international programme should lead to theorotical understanding of the progress of fires in buildings.

Further work is being carried out on the development of fires in the open, as this will have application both to forest fires and fires in built-up areas.

\section{Building Materials and Structures}

Since much of the total damage by fire occurs in buildings, this Section studies building materials under fire conditions to obtain basic data for the design and protection of structures which will help to control the development and spread of fire. It also performs, at the request of manufacturers, many tests on structural elements, and spread-of-flame tests on building materials. Its work is being used in the revision of building by-laws, and in the advice given to architects, builders, structural engineers and local authorities on appropriate types of structure and materials.

\section{Chemistry and Chemical Engineering}

This Section is concerned with industrial fires and explosions involving gases, vapours, dusts and unstable materials not classified as explosives. Working in close co-operation with the Factory Inspectorate of the Ministry of Labour, its aim is to assess hazards and devise precautionary measures. In collaboration with the Extinguishing Materials and Equipment Section, studies are made of the means of extinguishing fires in flammable liquids, the use of vapour phase inhibiting agents and the possibility of extinguishing fires in buildings by filling the interior with inert gas. Experiments with inert atmospheres are now being carried out with a specially adapted jet engine.

\section{Extinguishing Materials and Equipment}

The main purpose of this Section is to study the properties of, and methods of applying, extinguishing agents, for example, water, foam and dry powder. Models of rooms and buildings are used to learn more about the various mechanisms by which water puts out fires. This Section studies the automatic detection of fires and the performance of detection systems. It carries out tests-many of them for the Fire Offices' Committeo-on equipment, including automatic sprinkler systems, portable fire-extinguishing appliances, and automatic fire alarms. In co-operation with official bodies and manufacturers, the Section assists in drawing up standards and specifications for such equipment.

In addition, the Fire Research Station has a library which provides an extensive coverage of fire literature as well as information and intelligence services.

\section{FUTURE OF THE GENERAL DEGREE IN BRITISH UNIVERSITIES}

$\mathrm{D}^{\mathrm{T}}$ ISCUSSIONS at the Home Universities Conference are not required to reach agreed conclusions. Had this been the case, the discussion on the "Future of the General Degree" during the recent Conference of the Universities of the United Kingdom, held in London during December 9-10, would prob. ably have reached the conclusion that it is a good degree, but that it may have no future.

There were two opening speeches. The first was given by Mr. D. W. Reece, lecturer in humanity at the University of Aberdeen, who argued that the planned increase of student numbers to 170,000 , which will bring the proportion of students to total population in England to the same figure as it now is in Scotland, must (since there are no grounds to suppose that the English are more intelligent than the Scots) lead to the entry of a large number of students of lower calibre than hitherto, who will need easier courses of instruction. He assumed that the general degree in England can be equated to the ordinary degree in Scotland, and that there will be an increasing noed for it, as providing a suitable education for the less-able student.

The second opening speech, given by Prof. F. C. Frank (professor of physics, University of Bristol), dealt with the general degree with honours provided by most of the English universities, and in particular with the general degree of B.Sc. He took the opportunity to direct attention to the appalling complexity and disparity of terminology employed by various universities in describing the courses they offer. But while the general honours degrees are of various structure from university to university, broadly speaking they differ from special honours degrees mainly in the third year of study, which in a special degree is devoted to a single subject, whereas it still covers two or more subjects in a general degree.

The distinction between the special and the general degree ought not, Prof. Frank said, to be regarded as one of merit. He gave it as his considered judgment that in practice it is harder to get a first class in the general than in the special degree, though easier to get a poor second or a third class. It is judged to be a suitable career education for school-teaching, a course of education suited to the type of mind which is less happy concentrating on a narrow front, and a more balanced course for those whose intended future is a non-academic one (whereas the more academic will yet have time to take up their various academic subjects in turn). In short, he considered it a suitable education for a Cabinet Minister.

Judging from newspaper reports of the discusaion, it is probably the former conception of the general degree which appears more realistic outside university circles. This view was not without support at the Conference, but most speakers concerned themselves with the general honours degree : its merit was confirmed, but its name was brought in question. The 